\title{
Adaptation to overfeeding in man
}

\section{By J. A. Strong, Department of Medicine, Western General Hospital and R. PASSMORE, Department of Physiology, University of Edinburgh}

A short account of work carried out by the authors was given. A full presentation will be published (Strong, Shirling \& Passmore, I967). The summary of this paper is as follows:

Food which provided from 2960 to $7880 \mathrm{kcal}$ in excess of requirements was eaten by sixteen subjects, each for a period of 4 days.

The proportion of the nutrients lost in the faeces was not increased during overfeeding.

The metabolic rates were in no case increased by an amount equivalent to more than $15 \%$ of the excess calories. The increase could be attributed to the specific dynamic effect of the extra dietary protein.

The gains in weight ranged from 370 to $5460 \mathrm{~g} / 4$ days and the calorie equivalent of the weight gained varied from $\mathrm{I} \cdot \mathrm{I}$ to $10.0 \mathrm{kcal} / \mathrm{g}$. These variations can be attributed to variations in the amount of water retained.

Analysis of their respiratory exchanges suggests that most subjects stored from 400 to $1500 \mathrm{~g}$ carbohydrate in the tissues, possibly in the form of muscle glycogen.

REFERENCE

Strong, J. A., Shirling, D. \& Passmore, R. (1967). Br. F. Nutr. 2r, 909.

\section{The effect of changes in feeding patterns on the performance of pigs}

\author{
By R. BRAUDE, National Institute for Research in Dairying, \\ Shinfield, Reading
}

In feeding livestock, three basic questions must be considered: what, how much, and how to feed? The qualitative and quantitative aspects have been studied by many and information has accumulated which, though by no means complete, permits formulation of standards, requirements and allowances. It is only fairly recently that it has become clear that the problem of 'How should one feed' is of basic importance in nutrition, and that understanding of it may help to resolve some of the present controversies about feeding standards and requirements. The problem of how to feed is affected by so many factors that it is virtually impossible to arrive at any hard and fast rules or to make valid general recommendations. All one can do in a brief review is to draw attention to the many aspects of the problem and to some of its implications.

In Table I I have listed under three headings, some of the factors which may influence the pattern of feeding: those connected with the animal, those connected with the feed, and those connected with the management. The list is by no means complete, but it points to the complexity of the problem. It becomes even more 